\title{
Peranan Sektor Lapangan Usaha Dalam Meningkatkan PDRB Atas Dasar Harga Konstan di Provinsi Dki Jakarta Periode Tahun 2015-2019
}

\author{
Rina Nurlaeli Rachmawati Koerniawan, Amandus Jong Tallo \\ Fakultas Teknik dan Ilmu Komputer, Universitas Bakrie \\ rina.karyagavindo@yahoo.com \\ mandustallo@gmail.com
}

Received: 08 Juli 2020; Revised: 21 Agustus 2020; Accepted: 28 Agustus 2020 DOI: http://dx.doi.org/10.37905/aksara.6.2.97-102.2020

\begin{abstract}
Abstrak
Tingkat ekonomi Provinsi DKI Jakarta sebagai acuan perkembangan ekonomi di berbagai wilayah Indonesia. Produk Domestik Regional Bruto (PDRB) suatu daerah dapat dilihat dari lapangan usaha yang ada didaerah tersebut. Penelitian ini bertujuan untuk melihat tingkat PDRB di Provinsi DKI Jakarta pada sektor lapangan usaha. Hasil penelitian menunjukkan tiga sektor lapangan usaha yang berkontribusi besar diantaranya, sektor perdagangan besar dan eceran dan sektor resparasi mobil dan sepeda motor, sebesar $291,555,224.84$ juta rupiah $(15,94 \%)$. Sektor konstruksi sebesar 219,737,366.38 juta rupiah $(12,66 \%)$ dan sektor industri pengolahan menyumbang sebesar 217,046,499.37 juta rupiah $(12,49 \%)$. Daerah yang termasuk diantaranya, Jakarta Pusat sekitar 452,820,385.00 juta rupiah (24,43\%), Jakarta Selatan sekitar 394,620,056.42 juta rupiah $(22,68 \%)$ dan Jakarta Utara sekitar 333,659,786.51 juta rupiah $(18,36 \%)$. Daerah Kepulauan Seribu memberikan kontribusi terkecil sekitar 4,034,692.00 juta rupiah $(0,23$ $\%)$.
\end{abstract}

Kata Kunci : PDRB, DKI Jakarta, sektor, lapangan usaha, Kabupaten/kota.

\begin{abstract}
DKI Jakarta Province economic level as a reference for economic development in various regions of Indonesia. Gross Regional Domestic Product (GRDP) of an area can be seen from existing business fields in the area. This study aims to look at the level of GRDP in DKI Jakarta Province in the business sector. The results showed three business sectors that contributed greatly among them, the wholesale and retail trade sector and the car and motorcycle respector sector, amounting to 291,555,224.84 million rupiah (15.94\%). The construction sector amounted to 219,737,366.38 million rupiah (12.66\%) and the manufacturing sector contributed 217,046,499.37 million rupiah (12.49\%). The regions included, Central Jakarta around 452,820,385.00 million rupiah (24.43\%), South Jakarta around 394,620,056.42 million rupiah (22.68\%) and North Jakarta around 333,659,786.51 million rupiah (18.36\%). The Thousand Islands Region contributed the smallest around 4,034,692.00 million rupiah (0.23\%).
\end{abstract}

Keywords: Jakarta, GRDP, sector, business field, district. 


Volume : 06
Nomor $: 03$
Bulan $\quad:$ September 2020
Tahun $: 2020$
http

\section{Pendahuluan}

Faktor Ekonomi suatu Negara itu dikatakan maju, berkembang atau miskin. Saat ini Indonesia tidak lagi menjadi Negara berkembang, namun sudah naik menjadi Negara maju, hal ini dikarenakan bahwa Indonesia dianggap telah memiliki kekuatan ekonomi yang cukup baik. Pemerintah memberikan pengarahan kegiatan pembangunan ke berbagai daerah, terkhusus ke daerah yang emiliki tingkat kesejahteraan rendah (Dama et al., 2016).

Kondisi perekonomian Negara Indonesia yang cukup baik, tentu saja tercipta dari dukungan kondisi masing-masing wilayah di Negara Indonesia. Tingkat perekonomian Provinsi DKI Jakarta sangat berpengaruh yang menjadi acuan untuk tingkat perekonomian di wilayah Provinsi lainnya. Kota DKI Jakarta menjadi pusat perkembangan pemangunan dan perekonomian dengan tingginya tingkat urbanisasi (Malik et al., 2019).

Ekonomi pembangunan suatu wilayah mengacu pada Produk Domestik Bruto (PDB) atau Produk Domestik Regional Bruto (PDRB) (Cahyono et al., 2019). PDRB berfugsi untuk melihat kondisi perekonomian suatu wilayah atau daerah. Penelitian ini mennalisis tingkat perekonomian provinsi DKI Jakarta dilihat dari tingkat PDRB Atas Dasar Harga Konstan (ADHK) menurut sektor lapangan kerja periode Tahun 2015-2019.

Menurut BPS DKI Jakarta, PDRB Provinsi DKI Jakarta terdiri dari 17 sektor lapangan usaha diantaranya, 1) Pertanian, Kehutanan dan Perikanan, 2) Pertambangan dan Penggalian, 3) Industri Pengolahan, 4) Pengadaan listrik dan gas, 5) Pengadaan air, pengelolaan sampah, limbah dan daur ulang, 6) Konstruksi, 7) Perdagangan besar dan eceran; Resparasi mobil dan sepeda motor, 8) Transportasi dan pergudangan, 9) Penyediaan akomodasi dan makan minum, 10) Informasi dan komunikasi, 11) Jasa keuangan dan asuransi, 12) Real Estate, 13) Jasa perusahaan, 14) Administrasi pemerintahan, pertahanan dan jaminan sosial wajib, 15) Jasa pendidikan, 16) Jasa perusahaan, dan 17) Jasa lainnya. Peningkatan permintaan barang dan jasa dari berbagai macam sektor dari tahun sebelumnya menunjukkan pertumbuhan perekonomian suatu daerah (S et al., 2017).

Pentingnya peningkatan perekonomian membantu memperbaiki tingkat kemiskinan suatu daerah. Hal tersebut menunjukkan bahwa perlunya pemerataan pendapatan ekonomi di setiap wilayah (Romi \& Umiyati, 2018). Perbedaan tingkat ekonomi di setiap daerah beragam sehingga perlunya mengenali karakter ekonomi, sosial dan fisik setiap wilayah. Pemerintah daerah menjadi tonggak pendorong masyarakat dalam pemanfaatan dan pengembangan sumberdaya yang dimiliki untuk meningkatkan perekonomian daerah. Ekonomi potensial dapat ditingkatkan dengan mengolah pendapatan per kapita yang selaras dengan pertumbuhan pembangunan ekonomi (Safrianto et al., 2018).

\section{Metode}

Penelitian ini menggunakan metode kuantitatif yang menggunakan data sekunder dari Badan Pusat Statistik DKI Jakarta periode 2015-2019. Penulis juga melakukan penelitian kepustakaan dengan meninjau litertur terkait dari berbagai jurnal, serta sumber dokumentasi lainnya yang berhubungan dengan penelitian (library research) (Tallo et al., 2018). 


$\begin{array}{ll}\text { Volume }: 06 \\ \text { Nomor } & : 03 \\ \text { Bulan } & : \text { September } 2020 \\ \text { Tahun } & : 2020 \\ \text { http } & : \text { //ejurnal.pps.ung.ac.id/index.php/Aksara }\end{array}$

\section{Hasil dan Pembahasan}

\section{PDRB DKI Jakarta Pada Sektor Lapangan Usaha}

Tingkat Produk Domestik Regional Bruto (PDRB) Provinsi DKI Jakarta Pada Sektor Lapangan Usaha Berdasarkan Harga Konstan pada periode Tahun 2015 - 2019 adalah sebagai berikut :

Tabel 1. Peningkatan PDRB DKI Jakarta Menurut Lapangan (Juta Rupiah)

\begin{tabular}{|c|c|c|c|c|c|c|c|c|}
\hline \multirow[t]{2}{*}{ No } & \multirow[t]{2}{*}{ Lapangan Usaha } & \multicolumn{7}{|c|}{ PDRB Provinsi DKI Jakarta Atas Dasar Harga Konstan 2015-2019 } \\
\hline & & 2015 & 2016 & 2017 & 2018 & 2019 & rata - rata & Presentase \\
\hline 1 & Pertanian, Kehutanan dan Perikanan & $1,375,424.15$ & $1,387,526.30$ & $1,391,534.16$ & $1,394,394.28$ & $1,399,128.59$ & $1,389,601.50$ & $0.08 \%$ \\
\hline 2 & Pertambangan dan Penggalian & $2,956,158.19$ & $2,911,786.89$ & $2,916,305.65$ & $2,939,847.20$ & $2,850,913.43$ & $2,915,002.27$ & $0.18 \%$ \\
\hline 3 & Industri Pengolahan & $186,802,722.83$ & $193,625,440.62$ & $207,917,779.08$ & $219,717,892.64$ & $217,046,499.37$ & $205,022,066.91$ & $12.49 \%$ \\
\hline 4 & Pengadaan listrik dan gas & $3,923,966.43$ & $3,904,567.78$ & $4,344,531$ & $5,228,251.20$ & $5,867,741.54$ & $4,653,811.59$ & $0.28 \%$ \\
\hline 5 & $\begin{array}{l}\text { Pengadaan air, pengelolaan sampah, limbah } \\
\text { dan daur ulang }\end{array}$ & $651,812.67$ & $666,202.58$ & $685,690.60$ & $738,321.88$ & $759,862.09$ & $700,377.96$ & $0.04 \%$ \\
\hline 6 & Konstruksi & $195,804,652.04$ & $198,680,175.10$ & $208,861,695.68$ & $215,896,011.17$ & $219,737,366.38$ & $207,795,980.07$ & $12.66 \%$ \\
\hline 7 & $\begin{array}{l}\text { Perdagangan besar dan eceran; Resparasi } \\
\text { mobil dan sepeda motor }\end{array}$ & $234,748,205.58$ & $245,877,299.27$ & $259,765,281.78$ & $276,064,329.54$ & $291,555,224.84$ & $261,602,068.20$ & $15.94 \%$ \\
\hline 8 & Transportasi dan pergudangan & $45,905,152.88$ & $51,657,919.10$ & $56,260,550.56$ & $61,335,696.96$ & $66,516,628$ & $56,335,189.50$ & $3.43 \%$ \\
\hline 9 & Penyediaan akomodasi dan makan minum & $72,599,616.05$ & $76,873,466.42$ & $81,389,913.46$ & $85,779,669.67$ & $92,080,896.80$ & $81,744,712.48$ & $4.98 \%$ \\
\hline 10 & Informasi dan komunikasi & $141,500,796.44$ & $156,515,655.99$ & $172,427,806.18$ & $189,064,024.48$ & $210,976,326.98$ & $174,096,922.01$ & $10.61 \%$ \\
\hline 11 & Jasa keuangan dan asuransi & $155,162,978.35$ & $168,797,695.88$ & $178,831,057.72$ & $183,724,901.07$ & $199,101,639.43$ & $177,123,654.49$ & $10.79 \%$ \\
\hline 12 & Real Estate & $97,809,806.03$ & $102,395,776.93$ & $106,781,893.30$ & $111,551,390.33$ & $117,074,758.21$ & $107,122,724.96$ & $6.53 \%$ \\
\hline 13 & Jasa perusahaan & $106,646,597.80$ & $116,289,743.54$ & $128,237,349.54$ & $139,487,441.11$ & $155,121,490.20$ & $129,156,524.44$ & $7.87 \%$ \\
\hline 14 & $\begin{array}{l}\text { Administrasi pemerintahan, pertahanan dan } \\
\text { jaminan sosial wajib }\end{array}$ & $62,319,342.82$ & $64,388,948.49$ & $61,594,188.23$ & $67,893,776.26$ & $70,380,711.17$ & $65,315,393.39$ & $3.98 \%$ \\
\hline 15 & Jasa pendidikan & $71,210,273.30$ & $74,590,907.64$ & $75,905,203.04$ & $80,547,333.85$ & $85,165,963.43$ & $77,483,936.25$ & $4.72 \%$ \\
\hline 16 & Jasa kesehatan dan kegiatan sosial & $23,425,888.52$ & $25,255,984.26$ & $26,920,025.69$ & $28,666,633.95$ & $30,627,687.30$ & $26,979,243.94$ & $1.64 \%$ \\
\hline 17 & Jasa lainnya & $51,720,453.30$ & $56,097,784.26$ & $61,128,341.67$ & $66,261,129.59$ & $72,237,870.67$ & $61,489,115.90$ & $3.75 \%$ \\
\hline & Produk Domestik Regional Bruto & $1,454,563,847.38$ & $1,539,916,881.05$ & $1,635,359,147.34$ & $1,736,291,045.18$ & $1,838,500,708.43$ & $1,640,926,325.88$ & $100.00 \%$ \\
\hline
\end{tabular}

Lapangan usaha sebagai sumber pendapatan Produk Domestik Regional Bruto (PDRB) terinci dalam 17 sektor. Ke 17 sektor tersebut adalah 1) Pertanian, Kehutanan dan Perikanan, 2) Pertambangan dan Penggalian, 3) Industri Pengolahan, 4) Pengadaan listrik dan gas, 5) Pengadaan air, pengelolaan sampah, limbah dan daur ulang, 6) Konstruksi, 7) Perdagangan besar dan eceran; Resparasi mobil dan sepeda motor, 8) Transportasi dan pergudangan, 9) Penyediaan akomodasi dan makan minum, 10) Informasi dan komunikasi, 11) Jasa keuangan dan asuransi, 12) Real Estate, 13) Jasa perusahaan, 14) Administrasi pemerintahan, pertahanan dan jaminan sosial wajib, 15) Jasa pendidikan, 16) Jasa perusahaan, dan 17) Jasa lainnya.

Konstribusi terbesar bagi PDRB DKI Jakarta diantaranya, sektor Industri Pengolahan, Konstruksi, serta Perdagangan besar dan eceran; Resparasi mobil dan sepeda motor. Dari ketiga sektor tersebut, sektor Perdagangan besar dan eceran; Reparasi mobil dan sepeda motor, sebagai penyumbang terbesar PDRB DKI Jakarta Tahun 2019, yaitu sebesar 291,555,224.84 juta rupiah atau sekitar 15,94\%. Kemudian disusul oleh sektor konstruksi sebesar 219,737,366.38 juta rupiah atau sekitar 12,66 \% dan sektor industri pengolahan menyumbang sebesar 217,046,499.37 juta rupiah atau sekitar 12,49\%. Jika dibandingkan dengan tahun 2018 sektor industri pengolahan mengalami penurunan sekitar 2,671,393.27 juta rupiah atau 0,15 \% dari 219,717,892.64 juta rupiah ditahun sebelumnya.

Sementara itu ada tiga sektor yang memberikan kontribusi kecil terhadap PDRB Provinsi DKI Jakarta tahun 2019, yaitu Pertambangan dan Penggalian 2,850,913.43 juta 
Bulan : September 2020

Tahun : 2020

http : //ejurnal.pps.ung.ac.id/index.php/Aksara

rupiah atau sekitar 0,18\%, kemudian Pertanian, Kehutanan dan Perikanan sekitar $1,399,128.59$ juta rupiah atau sekitar $0,08 \%$, dan terakhir disusul oleh sektor Pengadaan air, pengelolaan sampah, limbah dan daur ulang sekitar 759,862.09 juta rupiah atau sekitar 0,04 \%. Hal ini dikarenakan kondisi geografis Provinsi DKI Jakarta tidak memungkinkan lapangan usaha dari ke tiga sektor tesebut memberikan kontribusi besar terhadap PDRB DKI Jakarta.

\section{Sumbangan Daerah Kabupaten/Kota Terhadap PDRB Provinsi DKI Jakarta}

Wilayah Kabupaten/kota Provinsi DKI Jakarta terbagi menjadi 6 wilayah yaitu, Kepulauan Seribu, Jakarta Selatan, Jakarta Timur, Jakarta Pusat, Jakarta Barat dan Jakarta Utara. Masing - masing wilayah Kabupaten/kota memberikan kontribusi yang berbeda - beda terhadap PDRB Provinsi DKI Jakarta setiap tahunnya.

Perekonomian di Provinsi DKI Jakarta berdasarkan dari sumbangan masing masing daerah Kabupaten/kota sejak tahun 2015 hingga tahun 2019 terus mengalami peningkatan. Tabel 2 mejelaskan tentang PDRB berdasarkan wilayah Kabupaten/kota di Provinsi DKI Jakarta tahun 2015 hingga 2019.

Tabel 2. PDRB Wilayah Provinsi DKI Jakarta Tahun 2015-2019 (Juta Rupiah)

\begin{tabular}{|c|c|c|c|c|c|c|c|c|}
\hline \multirow{2}{*}{ No } & \multirow{2}{*}{ Kab/Kota Administrasi } & \multicolumn{5}{|c|}{ PDRB } & \multirow[b]{2}{*}{ Rata-rata } & \multirow[b]{2}{*}{ Presentase } \\
\hline & & 2015 & 2016 & 2017 & 2018 & 2019 & & \\
\hline 1 & Kepulauan Seribu & $3,380,788.80$ & $3,815,300.00$ & $3,863,751.00$ & $3,934,692.00$ & $4,034,692.00$ & $3,805,844.76$ & $0.23 \%$ \\
\hline 2 & Jakarta Selatan & $329,155,038.27$ & $349,251,707.95$ & $371,253,513.45$ & $394,620,056.42$ & $421,746,236.29$ & $373,205,310.48$ & $22.68 \%$ \\
\hline 3 & Jakarta Timur & $249,476,978.00$ & $264,810,038.51$ & $281,363,139.62$ & $298,875,702.35$ & $314,044,942.37$ & $281,714,160.17$ & $17.12 \%$ \\
\hline 4 & Jakarta Pusat & $355,092,532.00$ & $377,781,738.00$ & $400,474,897.00$ & $424,324,595.00$ & $452,820,385.00$ & $402,098,829.40$ & $24.43 \%$ \\
\hline 5 & Jakarta Barat & $249,328,636.84$ & $264,434,925.84$ & $281,570,445.13$ & $299,577,448.66$ & $319,321,147.60$ & $282,846,520.81$ & $17.19 \%$ \\
\hline 6 & Jakarta Utara & $271,155,619.99$ & $283,654,318.62$ & $301,779,314.69$ & $320,778,645.38$ & $333,659,786.51$ & $302,205,537.04$ & $18.36 \%$ \\
\hline & jumlah & $1,457,589,593.90$ & $1,543,748,028.92$ & $1,640,305,060.89$ & $1,742,111,139.81$ & $1,845,627,189.77$ & $1,645,876,202.66$ & $100 \%$ \\
\hline
\end{tabular}

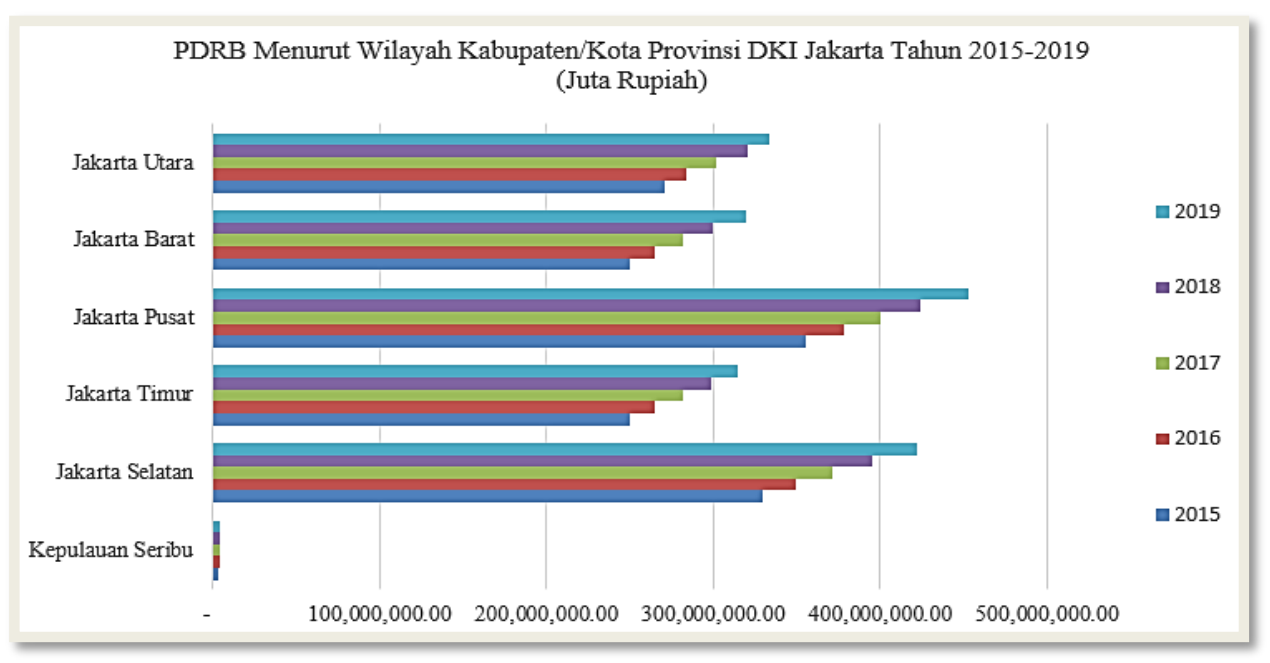

Gambar 1. Grafik PDRB Wilayah Provinsi DKI Jakarta Tahun 2015-2019 (Juta Rupiah) 




Berdasarkan data yang ada menunjukan bahwa ada tiga daerah yang memberikan sumbangan terbesar yaitu, daerah Jakarta Pusat sekitar 452,820,385.00 juta rupiah atau sekitar 24,43 \%, kemudian Jakarta Selatan sekitar 394,620,056.42 juta rupiah atau sekitar 22,68 \% dan disusul dengan Jakarta Utara 333,659,786.51 juta rupiah atau sekitar 18,36 $\%$. Sementara itu daerah Kepulauan Seribu memberikan kontribusi terkecil terhadap PDRB Provinsi DKI Jakarta tahun 2019 sekitar 4,034,692.00 juta rupiah atau sekitar 0,23 $\%$. Hal ini dipengaruhi oleh karakterikstik wilayah, jumlah penduduk, mata pencaharian, tingkat pendidikan, dan banyak faktor lainnya, sehingga setiap daerah kabupaten/kota menyumbangkan terhadap PDRB Provinsi DKI Jakarta berbeda - beda.

\section{Simpulan}

Berdasarkan data dan hasil yang sudah didapatkan, maka dapat ditarik kesimpulan bahwa :

1. Pertumbuhan PDRB Provinsi DKI Jakarta berdasarkan lapang usaha terdapat tiga sektor utama yang memberikan konstribusi terbesar yaitu, sektor Perdagangan besar dan eceran; Resparasi mobil dan sepeda motor yaitu sebesar 291,555,224.84 juta rupiah atau sekitar 15,94\%. Kemudian disusul oleh sektor konstruksi sebesar $219,737,366.38$ juta rupiah atau sekitar 12,66 \% dan sektor industri pengolahan menyumbang sebesar $217,046,499.37$ juta rupiah atau sekitar $12,49 \%$. Jika dibandingkan dengan tahun 2018 sektor industri pengolahan mengalami penurunan sekitar 2,671,393.27 juta rupiah atau 0,15\% dari 219,717,892.64 juta rupiah ditahun sebelumnya.

2. Sumbangan dari wilayah kabupaten/kota memberikan peranan nyata terhadap laju petumbuhan PDRB Provinsi DKI Jakarta. Daerah yang memberikan sumbangan terbanyak yaitu itu daerah Jakarta Pusat sekitar 452,820,385.00 juta rupiah atau sekitar 24,43\%, kemudian Jakarta Selatan sekitar 394,620,056.42 juta rupiah atau sekitar $22,68 \%$ dan disusul dengan Jakarta Utara 333,659,786.51 juta rupiah atau sekitar $18,36 \%$. Sementara itu daerah Kepulauan Seribu memberikan kontribusi terkecil terhadap PDRB Provinsi DKI Jakarta tahun 2019 sekitar 4,034,692.00 juta rupiah atau sekitar $0,23 \%$.

\section{Daftar Pustaka}

Cahyono, Almujab, S., Yogaswara, S. M., \& Pasundan, U. (2019). No Title. III, 39-48.

Dama, H. Y., Lapian, A. L. C., Sumual, J. I., Pembangunan, J. E., Ekonomi, F., Sam, U., \& Manado, R. (2016). PENGARUH PRODUK DOMESTIK REGIONAL BRUTO( PDRB ) TERHADAP TINGKAT KEMISKINAN DI KOTA MANADO. 16(03), 549561.

Malik, A. K., Galih, J. U., Bella, F., Perkotaan, M. K. P., Indonesia, U., (BPPT), S. B. P. dan P. T., \& Jakarta. (2019). QUALITY OF LIFE AND ECONOMIC GROWTH, CASE STUDY OF DKI JAKARTA AND SUB. 3, 227-247.

Romi, S., \& Umiyati, E. (2018). Pengaruh pertumbuhan ekonomi dan upah minimum terhadap kemiskinan di Kota Jambi. 7(1), 1-7.

S, T. F., Kusreni, S., Bisnis, F. E. dan, \& Airlangga, U. (2017). Jurnal Ilmu Ekonomi Terapan Determinan Pertumbuhan Ekonomi di 4 Negara ASEAN. 02(1), 10-20.

Safrianto, Y., Ekonomi, F., Umar, U. T., \& Meulaboh. (2018). Analisis faktor-faktor yang mempengaruhi pertumbuhan ekonomi di kabupaten simeulue. 




Volume : 06

Nomor : 03

Bulan : September 2020

Tahun : 2020

http : //ejurnal.pps.ung.ac.id/index.php/Aksara

Tallo, A. J., Arianti, S. P., Abdillah, F., \& Syaiful, A. (2018). Typology Analysis and Leading Sector of East Nusa Tenggara Province in 2017 Typology Analysis and Leading Sector of East Nusa Tenggara Province in 2017. 